\title{
Congenital Supraventricular Tachycardia
}

National Cancer Institute

\section{Source}

National Cancer Institute. Congenital Supraventricular Tachycardia. NCI Thesaurus. Code C101197.

A disorder present at birth characterized by an electrocardiographic finding of a tachycardia that originates above the ventricles. 